\title{
POLA KOMUNIKASI ORANG TUA DAN ANAK DI DESA SUKOLILO KECAMATAN JABUNG MALANG
}

\author{
Imamatus Sholihah 1 ) \\ 1)IAI Sunan Kalijogo Malang \\ 1)Imamatussh10@gmail.com
}

\begin{abstract}
Abstrak. Komunikasi antarorang tua dan anak sangat diperlukan, karena perkembangan emosi anak dipengaruhi oleh perubahan pola interaksi dan pola komunikasi dalam keluarga. Komunikasi keluarga pada hakikatnya adalah suatu proses penyampaian pesan bapak atau ibu sebagai komunikator kepada anak-anak sebagai komunikan tentang norma-norma atau nilai-nilai yang berlaku dalam keluarga, dengan tujuan keutuhan dan pembentukan keluarga yang harmonis. Pengalaman interaksi di dalam keluarga akan menentukan pola dan tingkah laku anak terhadap orang lain dalam masyarakat. Ada sejumlah norma yang diwariskan orang tua pada anak, misalnya norma agama, norma akhlak, norma sosial, norma etika dan estetika, dan juga norma moral. Tujuan penelitian ini adalah mengetahui pola komunikasi orang tua terhadap anak di desa sukolilo, demi terciptanya pembentukan nilai-nilai positif dalam sebuah keluarga. Dalam penelitian ini menggunakan pendekatan kualitatif deskriptif, dengan metode pengumpulan data menggunakan observasi, sedangkan obyek penelitiannya adalah masyarakat didesa sukolilo kecamatan jabung Malang. Hasil dari analisis penelitian ini ialah pola komunikasi orang tua dengan anak di desa sukolilo ada 3 macam; Authoritarian/otoriter (cenderung bersikap bermusuhan), Permissive (cenderung berperilaku bebas), dan Authoritative (cenderung terhindar dari kegelisahan dan kekacauan), pola komunikasi demokratis umumnya ditandai dengan adanya sikap terbuka antara orangtua dan anak. Dengan adanya komunikasi yang baik antar keluarga, membantu meningkatkan nilai-nilai kepatuhan di dalam diri masing-masing individu dan tercipta keluarga yang rukun, harmonis dan sejahtera.
\end{abstract}

Kata Kunci: Pola, Komunikasi, Pola Komunikasi Orang Tua dan Anak.

Abstract. Communication between parents and children is very necessary, because the emotional development of children is influenced by changes in interaction patterns and communication patterns in the family. Family communication is essentially a process of delivering messages from father or mother as communicators to children as communicants about norms or values that apply in the family, with the aim of wholeness and the formation of a harmonious family. The experience of interaction in the family will determine the pattern and behavior of children towards other people in society. There are a number of norms that are passed on from parents to children, such as religious norms, moral norms, social norms, ethical and aesthetic norms, and also moral norms. The purpose of this study was to determine the communication patterns of parents to children in the village of Sukolilo, in 
order to create the formation of positive values in a family. In this study using a descriptive qualitative approach, with the method of collecting data using observation, while the object of research is the community in the Sukolilo village, Jabung sub-district, Malang. The result of this research analysis is that there are 3 kinds of communication patterns between parents and children in the village of Sukolilo; Authoritarian/authoritarian (tends to be hostile), Permissive (tends to behave freely), and Authoritative (tends to avoid anxiety and chaos), democratic communication patterns are generally characterized by an open attitude between parents and children. With good communication between families, it helps to increase the values of obedience in each individual and creates a harmonious, harmonious and prosperous family.

Keywords: Pattern, Communication, Parent and Child Communication Pattern.

\section{PENDAHULUAN}

Manusia adalah makhluk sosial, artinya makhluk itu hidup dengan manusia lainnya yang satu sama lain saling membutuhkan, untuk melangsungkan kehidupannya manusia berhubungan dengan manusia lainnya. Hubungan antar manusia akan tercipta melalui komunikasi, baik komunikasi verbal (bahasa) maupun nonverbal (simbol, gambar, atau media komunikasi lainnya). Komunikasi adalah sesuatu yang tidak dapat dipisahkan dari kehidupan manusia, sejak pertama menusia itu dilahirkan manusia sudah melakukan proses komunikasi. ${ }^{1}$ Setiap individu pasti melakukan interaksi dengan individu lain yang berbeda-beda dalam kehidupan sehari-harinya. Baik itu dari segi pendidikan, status sosial, usia, hingga latar belakang budaya. ${ }^{2}$ Perbedaan-perbedaan yang dijumpai dalam proses komunikasi dengan orang lain memerlukan penyesuaian yang tepat, sehingga komunikasi dapat berlangsung dengan baik dan efektif. Penyesuaian yang tepat tersebut dibutuhkan supaya tidak terjadi kesalahpahaman dalam proses komunikasi yang dapat berakibat kegagalan mencapai tujuan komunikasi, atau dapat pula memicu konflik. Konflik yang ditimbulkan dapat berupa perkelahian, perdebatan, kerenggangan hubungan pertemanan, hingga permusuhan.

\footnotetext{
1 Sherly Citra, Pola Komunikasi Orangtua Dengan Anak Perokok Aktif Di Surabaya, (Surabaya: UPN Veteran, 2010), 01.

2 Fahrul Hidayat, Aprezo Pardodi Maba, and Hernisawati, "Perspektif Bimbingan Dan Konseling Sensitif Budaya," Konseling Komprehensif, volume 5, no. 1 Mei (2018), 31-41.
} 
Komunikasi memiliki peran yang penting dalam kehidupan manusia, terutama komunikasi antara orang tua dan anak harus dijaga keefektifannya supaya komunikasi yang terjadi dapat harmonis dan komunikasi yang disampaikan dapat ditangkap dan dicerna dengan baik dari orangtua kepada anak dan sebaliknya dari anak kepada orangtua. Intensitas dalam melakukan komunikasi merupakan suatu tingkat kedalaman dalam menyampaikan suatu pesan dari seorang individu sebagai anggota keluarga kepada keluarga atau orang lain yang berada disekitarnya. ${ }^{3}$ Terdapat hal yang penting yang harus dimiliki dan dilakukan saat melakukan komunikasi yaitu: kejujuran, keterbukaan, pengertian, rasa percaya dan dukungan antara kedua belah pihak. ${ }^{4}$ Intensitas dalam berkomunikasi pada keluarga penting dilakukan, karena komunikasi dapat mempererat hubungan keluarga dan dapat menciptakan rasa aman dan nyaman.

Keluarga merupakan lingkungan sosial pertama dan utama bagi anak sehingga memberi pengaruh terbesar bagi perkembangan anak dengan begitu orang tua terutama ayah dan ibu memberikan dasar pembentukan tingkah laku, pendidikan serta cara berinterakasi dengan lingkungannya. Pengalaman interaksi di dalam keluarga akan menentukan pola dan tingkah laku anak terhadap orang lain dalam masyarakat. Ketika orang tua memberikan kebebasan kepada anak untuk banyak bergaul dengan teman sebayanya maka anak akan lebih terbuka untuk menerima dunia luar, lebih mandiri, dan mempunyai perkembangan sosial yang lebih baik. Jadi orang tua harus memberikan kesempatan pada anak untuk berinteraksi dengan orang lain maupun teman-temannya, sehingga anak merasakan adanya kehangatan dari orang tua mereka perhatikan, perawatan dan kasih sayang yang diterima anak mengajarkan bahwa dalam hubungan dengan orang lain juga harus dilandasi oleh rasa kasih sayang, empati, maupun toleransi.

Komunikasi dalam keluarga dapat berlangsung secara timbal balik dan silih berganti, bisa dari orang tua ke anak atau dari anak ke orang tua ataupun anak ke

3 Djamarah, S. B. (2004). Pola Komunikasi Orang Tua dan Anak dalam Keluarga: Sebuah Perspektif Pendidikan Islam. (Jakarta: Rineka Jaya, 2004).

4 Kamumu R. (2012).Hubungan antara komunikasi efektif orang tua dan anak dengan tingkat stress pada remaja siswa SMK Negri Jogjakarta. http://www.ejurnal.com/2013/09/hubunganantarakomunikasi-efektif.html. Diakses pada tanggal 27 Mei 2021. 
anak. Dalam komunikasi keluarga, tanggung jawab orang tua adalah mendidik anak, maka komunikasi yang terjadi dalam keluarga bernilai pendidikan. Ada sejumlah norma yang diwariskan orang tua pada anak, misalnya norma agama, norma akhlak, norma sosial, norma etika dan estetika, dan juga norma moral. Pemahaman dan kesadaran keluarga mengenai pentingnya komunikasi keluarga dan pengaruhnya terhadap perkembangan emosi anak masih tergolong rendah, hal ini penting untuk diperhatikan karena keadaan emosional pada anak masih labil, dan penyampaian komunikasi oleh orangtua kepada anak harus memperhatikan keadaan emosional anak. Orangtua dapat menempatkan diri sesuai dengan yang anak inginkan dan di mengerti oleh anak, karena apabila penyampaian komunikasi pada anak salah maka akan meningkatkan tingkat stres pada anak. Sebaliknya apabila orangtua dapat berkomunikasi dengan baik kepada anak, maka komunikasi tersebut dapat mengurangi stress yang anak alami. ${ }^{5}$

Kecenderungan terjadinya stres pada anak dapat dipengaruhi oleh komunikasi yang kurang efektif antara orangtua dan anak, yang berarti bahwa apabila terjalin suatu komunikasi efektif maka akan mengurangi tingkat stress pada anak. Komunikasi yang efektif juga membuat anak memiliki motivasi belajar yang positif atau motivasi belajar yang tinggi, sehingga anak dapat meraih hasil prestasi yang baik dan dapat memberikan kepuasan pada anak dan orangtua. Dampak komunikasi yang dilakukan tidak disertai kejujuran, keterbukaan, dan rasa saling percaya adalah menyebabkan anak kurang bertanggung jawab terhadap tugas yang harus dikerjakannya, kurang bekerja keras, tidak menyukai atau lemah dalam umpan balik, tidak tergantung untuk menyelesaikan tugas secepat mungkin, serta kurang mampu untuk menentukan dan menetapkan tujuan yang sesuai dengan kemampuannya. ${ }^{6}$

Perhatian Islam terhadap hak-hak anak mengisyaratkan bahwa anak harus mendapatkan apresiasi sebagaimana orang dewasa, bahkan anak-anak lebih sensitive terhadap masalah-masalah sosial di lingkungannya, sehingga pendidikan, bimbingan

5 Setyowati, Pola Komunikasi Keluarga Dan Perkembangan Emosi Anak-Anak (Studi Kasus Penerapan Pola Komunikasi Keluarga Dan Pengaruhnya Terhadap Perkembangan Emosi Anak Pada Keluarga Jawa), 2005, 67-78.

${ }^{6}$ Siti Zulaekhah dan Zubaidah, Hubungan Pola Komunikasi Orangtua Dengan Motivasi Belajar, Universitas Diponegoro, 236, jurnal diakses pada tanggal 27 Mei 2021. 
dan perhatian terhadap anak lebih tinggi intensitasnya agar mereka dapat melalui proses tumbuh kembang secara wajar. ${ }^{7}$ Komunikasi orang tua terhadap anak termasuk dapat mempengaruhi pembentukan baik buruknya perilaku anak tersebut. Perilaku seseorang adalah gabungan hasil faktor-faktor kognisi dan lingkungan. ${ }^{8}$ Faktor kognisi berupa daya tangkap, daya ingat, pengertian, serta penilaian anak terhadap suatu hal, sedangkan faktor lingkungan adalah tempat di mana anak tumbuh dan berkembang, mereka belajar dari interaksi sosial dari lingkungan tersebut. $^{9}$

Dalam lingkungan, anak tidak hanya mengenal tentang kehidupan positif seperti tolong menolong, bekerjasama, menghargai orang lain, tetapi juga mempelajari hal-hal lainnya, di mana salah satunya adalah motivasi untuk belajar, yang didasarkan pada aspek peniruan sebagaimana dicontohkan oleh lingkungan keluarga dan lingkungan sosialnya. Anak akan menyerap dan memahami informasi serta pesan-pesan yang mengandung nilai-nilai pendidikan dari lingkungan keluarga, misalnya tentang bagaimana orang-orang berperilaku hemat, tekun dan disiplin dalam belajar, yang mana hal-hal tersebut akan menjadi semacam pengetahuan bagi anak. Efek secara sikap dalam hal ini anak akan meniru simbol, kebiasaan yang diambil dari interaksi sosial dan sebagainya, terutama dari lingkungan keluarganya. Hal tersebut memberikan hasrat positif pada peneliti untuk menganalisis pola komunikasi orang tua terhadap anak di desa sukolilo kecamatan jabung, demi terciptanya nilai-nilai positif dalam sebuah keluarga. Dalam jurnal ini, hemat peneliti terkait analisis pola komunikasi orang tua terhadap anak di desa sukolilo akan dipaparkan pada poin pembahasan.

\section{METODE PENELITIAN}

Penelitian ini menggunakan pendekatan kualitatif deskriptif. Dengan metode pengumpulan data menggunakan observasi. Sedangkan obyek penelitiannya adalah masyarakat di desa sukolilo kecamatan jabung Malang.

${ }^{7}$ Mufidah, Psikologi Keluarga Islam Berwawasan Gender, (Malang: UIN Maliki Press, 2013), 271

${ }^{8}$ Rakhmat, Psikologi komunikasi, (Bandung: Remaja Rosdakarya), 2004, 238

${ }^{9}$ Surbakti, E. B, Sudah siapkah menikah?. (Jakarta: Media Komputindo, 2008), 239 


\section{HASIL DAN PEMBAHASAN}

Kata komunikasi atau communication dalam bahasa inggris berasal dari kata communis yang berarti "sama", comunico, communication, atau communicare yang berarti "membuat sama" (to make common). Judy C. Pearson dan Paul E. Nelson mengemukakan bahwa komunikasi mempunyai dua fungsi umum. Pertama, untuk kelangsungan hidup diri sendiri yang meliputi: keselamatan fisik, meningkatkan kesadaran pribadi. Kedua, untuk kelangsungan hidup masyarakat, tepatnya untuk memperbaiki hubungan sosial dan mengembangkan keberadaan suatu masyarakat. Pola komunikasi adalah kecenderungan gejala umum yang menggambarkan bagaimana cara berkomunikasi yang terjadi dalam kelompok sosial tertentu. Setiap kelompok sosial dapat menciptakan norma sosial dan juga norma komunikasi. Pola komunikasi dipengaruhi oleh proses komunikasi yang dilakukan. Setelah itu akan ditemukan pola komunikasi yang terbentuk melalui proses komunikasi tersebut. ${ }^{10}$ Pola komunikasi yang terbentuk pada orang tua dan anak disebabkan adanya komunikasi di kehidupan sehari-hari dengan pembahasan yang berbeda-beda.

Hubungan yang dijalin akan berjalan baik, apabila komunikasi diantara satu dengan yang lain berjalan dengan efektif. Oleh karena itu, mengingat pentingnya komunikasi, seiring berkembangnya kehidupan manusia muncul yang namanya teori komunikasi. Teori Komunikasi merupakan suatu pemikiran mengenai sistem penyampaian pesan yang didalamnya terdiri atas komponen-komponen berupa unsur komunikasi. Komponen - komponen tersebut saling terikat demi tersampainya pesan dari komunikator kepada komunikan. Dalam perkembangannya, banyak para ahli yang mendefinisikan mengenai teori komunikasi. Salah satu yang sering menjadi rujukan adalah pendapat Borman, berpendapat bahwa teori komunikasi adalah suatu istilah atau perkataan yang merupakan seluruh perbincangan dan analisis dan dibuat secara berhati-hati, sistematik dan sadar. Selain itu Little John berpendapat bahwa teori komunikasi merupakan sutu teori atau pemikiran kolektif. Di dalamnya, terdapat keseluruhan teori terutama yang berkaitan tentang proses komunikasi. Kemudian Cargan dan Shield berpendapat bahwa teori komunikasi adalah hubungan

10 W Suranto, Komunikasi Sosial Budaya (Yogyakarta: Graha Ilmu, 2010), 116 
diantara konsep teoritikal yang memberi secara keseluruhan maupun sebagian keterangan, penjelasan, peilanian, maupun perkiraan tindakan manusia berdasarkan komunikator yang berkomunikasi (berbicara, membaca, mendengar, menonton) untuk jangka waktu tertentu melalui media (perantara).

Perkembangan teori komunikasi merupakan studi yang berkembang pesat dibandingkan dengan studi lain. Para ahli pun banyak yang memberikan sumbangsih pada studi ini, sehingga mengakibatkan cangkupan studi ini menjadi luas sebagai timbal balik dari berbagai jenis teori komunikasi yang ditemukan, penjelasan jenisjenis teori komunikasi menurut para ahli sebagai berikut;

\section{a. Teori Komunikasi Behaviorisme}

Jenis teori komunikasi yang satu ini mungkin sangat sering anda dengar. Teori ini dikembangkan oleh ilmuan asal Amerika Serikat bernama Jhon B. Watson (1878 1958). Menurutnya Teori Behaviorisme ini mencakup semua perilaku, termasuk tindakan balasan atau respon terhadap suatu rangsangan atau stimulus. Artinya bahwa selalu ada kaitan antara stimulus dengan respon pada perilaku manusia. Jika suatu stimulus atau rangsangan yang diterima seseorang telah teramati, maka dapat diprediksikan pula respon dari orang tersebut.

b. Teori Komunikasi Humanisme

Komunikasi humanisme pernah diimplementasikan dalam dunia pendidikan melalui Humanistic curriculum. Isi teori lebih menekankan pada pembagian pengawasan dan tanggung jawab bersama antar peserta didik. Dengan harapan, nantinya peserta didik dapat menyesuaikan dalam kehidupan masyarakat.

c. Teori Belajar Sosial

Perilaku manusia dalam konteks sebuah interaksi tingkah laku terdapat hubungan timbal baik yang saling berkesinambungan. Interaksi terjadi antara perilaku kognitif dan pengaruh lingkungan. Pengalaman melalui observasi dan pengamatan terhadap suatu pesan yang disampaikan menjadi suatu hal yang penting dalam teori ini. Dalam teori ini, terdapat empat tahapan, pertama pembelajaran sosial terjadi atas adanya perhatian dari individu. Kedua, pembelajaran sosial dilakukan melalui ingatan. Ketiga, pembelajaran sosial dilakukan melalui tindakan, serta terakhir yaitu pembelajaran sosial dilakukan atas dasar motivasi dari masing-masing individu. 


\section{d. Teori Operant Conditioning (Skinner)}

Teori ini pertama kali dikemukakan oleh Skinner (1904-1990). Skinner menganggap penghargaan dan motivasi adalah dua faktor penting dalam pembelajaran. Tak hanya itu, Skinner berpendapat bahwa tujuan psikologi dalam komunikasi adalah untuk mengontrol tingkah laku. Pada teori ini, seorang guru memberikan penghargaan hadiah atau nilai tinggi yang bertujuan agar anak menjadi lebih rajin. Di sisi lain, Operant conditioning merupakan suatu proses pemberian motivasi terhadap suatu perilaku yang kemudian mengakibatkan perilaku tersebut dapat terulang atau menghilang sesuai keinginan. Kemudian, Operant conditing menjamin respon terhadap stimuli. Bila tidak ada tanda - tanda keberadaan stimuli, maka guru tidak bisa membimbing siswa untuk mengarahkan perilakunya. Dalam proses ini, guru mempunyai peran untuk mengontrol dan membimbing siswa dalam suatu proses belajar. Hal ini bertujuan untuk mencapai tujuan belajar yang diinginkan.

Keluarga merupakan lingkungan sosial pertama dan utama bagi anak sehingga memberi pengaruh terbesar bagi perkembangan anak dengan begitu orang tua terutama ayah dan ibu memberikan dasar pembentukan tingkah laku, pendidikan serta cara berinterakasi dengan lingkungannya. Keluarga merupakan lingkungan yang kondusif bagi sosialisasi anak. Perkembangan sosial anak dalam tahapan kemampuan anak dalam berprilaku sesuai dengan harapan lingkungan. ${ }^{11}$ Komunikasi keluarga pada hakikatnya adalah suatu proses penyampaian pesan bapak atau ibu sebagai komunikator kepada anak-anak sebagai komunikan tentang norma-norma atau nilai-nilai yang berlaku dalam keluarga, dengan tujuan keutuhan dan pembentukan keluarga yang harmonis. Pengalaman interaksi di dalam keluarga akan menentukan pola dan tingkah laku anak terhadap orang lain dalam masyarakat. Ketika orang tua memberikan kebebasan kepada anak untuk banyak bergaul dengan teman sebayanya maka anak akan lebih terbuka untuk menerima dunia luar, lebih mandiri, dan mempunyai perkembangan sosial yang lebih baik. Begitu orang tua memberikan kesempatan pada anak untuk berinteraksi dengan orang lain maupun

11 Levia Wina dkk, Hubungan Pola Asuh Orang Tua Dengan Perkembangan Sosial Anak Usia Prasekolah (4-6 Tahun) Di Tk Muslimat Ar-Rohmah Gading Kembar Kecamatan Jabung Kabupaten Malang, Universitas Tribhuwana Tunggadewi Malang, 170, jurnal diakses pada tanggal 27 Mei 2021. 
teman-temannya, sehingga anak merasakan adanya kehangatan dari orang tua mereka perhatikan, perawatan dan kasih sayang yang diterima anak mengajarkan bahwa dalam hubungan dengan orang lain juga harus dilandasi oleh rasa kasih sayang, empati, maupun toleransi.

Motivasi belajar anak tiada lain adalah memanfaatkan sebagaimana sering dicontohkan oleh lingkungan keluarga, terutama orangtua dan sekedar memanfaatkan waktu luang, atau mengetahui perkembangan pengetahuan. Anak terpacu untuk belajar semata untuk memahami proses internalisasi nilai-nilai masa kini yang sedang berkembang dalam rangka menyiapkan prestasi belajar yang optimal. Informasi apa yang mereka peroleh dari lingkungan dan lingkungan keluarga dapat mempengaruhi cara mereka merasakan, berpikir, bersikap dan berperilaku sesuai dengan obyek yang dikonsumsi. ${ }^{12}$ Apabila dukungan belajar dari lingkungan keluarga berjalan dengan baik maka anak akan memiliki motivasi belajar yang tinggi, yang pada akhirnya anak akan dapat meningkatkan prestasi akademiknya. Anak yang memiliki motivasi belajar yang tinggi akan mendapatkan prestasi yang maksimal. Oleh sebab itu pola hubungan komunikasi antara orangtua dan anak sangat penting dilakukan karena dapat berdampak besar terhadap prestasi akademik anak. Keterlibatan orangtua dalam mendidik dan mendukung anaknya memberikan pengaruh besar kepada motivasi belajar anak. Hal ini terjadi karena orangtua selalu melakukan komunikasi dengan intensitas yang sering dan saling memberikan umpan balik sehingga anak menjadi nyaman dalam berkomunikasi dengan orangtuanya. Komunikasi yang efektif antara anak dan orangtua dapat membuat anak memiliki motivasi belajar yang positif atau motivasi belajar yang tinggi, sehingga anak dapat meraih hasil prestasi yang baik dan dapat memberikan kepuasan pada anak dan orangtua.

Kegiatan komunikasi yang dilakukan dapat terjadi dalam berbagai macam situasi atau tingkatan, yaitu intrapribadi, antarpribadi, kelompok dan massa. Sebagian besar kegiatan komunikasi yang dilakukan oleh manusia berlangsung dalam situasi atau tingkatan komunikasi antarpribadi. Tingkatan komunikasi

${ }^{12}$ Amalia, L, Mitos Cantik Di Media, (Ponorogo: STAIN Press, 2009), 240 
antarpribadi dapat ditemui dalam konteks kehidupan dua orang, keluarga, kelompok maupun organisasi. Melalui komunikasi antarpribadi seseorang dapat menjalin hubungan yang lebih bermakna atau menjalin persahabatan dengan baik. Selain itu, melalui komunikasi seorang individu dapat membantu menyelesaikan persoalan yang sedang dialami oleh individu lain dan seseorang dapat mengubah nilai-nilai dan sikap hidup orang lain menjadi lebih baik. Komunikasi dalam keluarga dapat berlangsung secara timbal balik bisa dari orang tua ke anak atau dari anak ke orang tua ataupun anak ke anak. Dalam komunikasi keluarga, tanggung jawab orang tua adalah mendidik anak, maka komunikasi yang terjadi dalam keluarga bernilai pendidikan atau kea rah positif. Ada sejumlah norma yang diwariskan orang tua pada anak, misalnya norma agama, norma akhlak, norma sosial, norma etika dan estetika, dan juga norma moral.

Berdasarkan hasil observasi peneliti dapat dianalisis bahwa proses komunikasi antarorang tua dan anak sangat diperlukan, karena perkembangan emosi anak dipengaruhi oleh perubahan pola interaksi dan pola komunikasi dalam keluarga. Pola komunikasi orang tua terhadap anak di desa sukolilo sangat bervariasi, adapun macam-macam pola komunikasi orangtua pada anak, yaitu:

a. Authoritarian/otoriter (cenderung bersikap bermusuhan), pola komunikasi ini sikap orangtua untuk menerima sangat rendah, namun kontrolnya sangat dominan sehingga sering terjadi hukuman secara fisik, cenderung emosional dan bersikap menolak. Sedangkan anak menjadi mudah tersinggung, penakut dan merasa tidak bahagia, mudah terpengaruh dan tidak mempunyai arah masa depan yang jelas serta tidak bersahabat.

b. Permissive (cenderung berperilaku bebas), pola komunikasi ditandai dengan adanya kebebasan tanpa batas seperti memberikan kebebasan pada anak untuk menyatakan keinginannya. Sedangkan anak bersikap impulsive serta agresif, kurang memiliki rasa percaya diri, suka mendominasi, tidak jelas arah hidupnya serta dalam bidang pendidikan prestasinya rendah.

c. Authoritative (cenderung terhindar dari kegelisahan dan kekacauan), pola komunikasi demokratis umumnya ditandai dengan adanya sikap terbuka antara orangtua dan anak. Dalam hal ini sikap orangtua untuk menerima dan kontrolnya 
tinggi terhadap anak, selain itu bersikap responsive terhadap kebutuhan anak, mendorong anak untuk menyatakan pendapat atau pertanyaan, orangtua memberikan penjelasan tentang dampak perbuatan yang baik dan buruk. Sedangkan anak bersikap bersahabat, memiliki rasa percaya diri, mampu mengendalikan diri (self control) bersikap sopan, memiliki rasa ingin tahu yang tinggi dan memiliki tujuan atau arah hidup yang jelas serta berorientasi terhadap prestasi.

Sikap orang tua yang cenderung dominan dan hak orang tua atas diri anak adalah mutlak, sehingga tidak ada orang tua yang bertindak melebihi batas atas diri anaknya. Orangtua yang dapat memahami keinginan anaknya yang telah menginjak remaja, biasanya orang tua sejak awal telah membekali pendidikan, bimbingan dan arah yang baik, sehingga anaknya berhati-hati dalam pergaulan sehari-hari. Dengan adanya komunikasi yang baik antar keluarga, membantu meningkatkan nilai-nilai kepatuhan di dalam diri masing-masing individu dan tercipta keluarga yang rukun, harmonis dan sejahtera.

\section{KESIMPULAN DAN SARAN}

\section{Simpulan}

Komunikasi keluarga pada hakikatnya adalah suatu proses penyampaian pesan bapak atau ibu sebagai komunikator kepada anak-anak sebagai komunikan tentang norma-norma atau nilai-nilai yang berlaku dalam keluarga, dengan tujuan keutuhan dan pembentukan keluarga yang harmonis. Pengalaman interaksi di dalam keluarga akan menentukan pola dan tingkah laku anak terhadap orang lain dalam masyarakat. Kegiatan komunikasi yang dilakukan dapat terjadi dalam berbagai macam situasi atau tingkatan, yaitu intrapribadi, antarpribadi, kelompok dan massa. Sebagian besar kegiatan komunikasi yang dilakukan oleh manusia berlangsung dalam situasi atau tingkatan komunikasi antarpribadi.

Proses komunikasi antarorang tua dan anak sangat diperlukan, karena perkembangan emosi anak dipengaruhi oleh perubahan pola interaksi dan pola komunikasi dalam keluarga. Pola komunikasi orang tua terhadap anak di desa sukolilo sangat bervariasi, adapun macam-macam pola komunikasi orangtua pada 
anak, ada 3 macam yaitu; Authoritarian/otoriter (cenderung bersikap bermusuhan), Permissive (cenderung berperilaku bebas), dan Authoritative (cenderung terhindar dari kegelisahan dan kekacauan), pola komunikasi demokratis umumnya ditandai dengan adanya sikap terbuka antara orangtua dan anak.

\section{Saran}

Peneliti beranggapan bahwa penting sekali komunikasi antar orang tua dan anak dilakukan dalam berbagai hal, baik pendidikan, kehidupan sosial maupun percintaan yang mayoritas dialami awal masa remaja. Dengan adanya komunikasi yang baik antar keluarga, membantu meningkatkan nilai-nilai kepatuhan di dalam diri masing-masing individu dan tercipta keluarga yang rukun, harmonis dan sejahtera. Pola komunikasi yang sangat relevan dalam kehidupan keluarga adalah pola komunikasi demokratis, karena sikap orangtua untuk menerima dan kontrolnya tinggi terhadap anak, selain itu bersikap responsive terhadap kebutuhan anak, sedangkan anak bersikap bersahabat, memiliki rasa percaya diri, mampu mengendalikan diri (self control) dan berorientasi terhadap kesuksesan dalam hidupnya. 


\section{REFERENSI}

Djamarah, S. B. Pola Komunikasi Orang Tua dan Anak dalam Keluarga: Sebuah Perspektif Pendidikan Islam. Jakarta: Rineka Jaya. 2004.

Setyowati, Y. Pola Komunikasi Keluarga Dan Perkembangan Emosi Anak-Anak. (Studi Kasus Penerapan Pola Komunikasi Keluarga Dan Pengaruhnya Terhadap Perkembangan Emosi Anak Pada Keluarga Jawa). Jurnal Ilmu Komunikasi. 2005.

Zulaekhah, Siti dan Zubaidah. Hubungan Pola Komunikasi Orangtua Dengan Motivasi Belajar. Universitas Diponegoro, jurnal diakses pada tanggal 27 Mei 2021.

Kamumu R. Hubungan Antara Komunikasi Efektif Orang Tua Dan Anak Dengan Tingkat Stress Pada Remaja Siswa SMK Negri Jogjakarta. 2012.

Hidayat dkk. Perspektif Bimbingan Dan Konseling Sensitif Budaya. Konseling Komprehensif Volume 5, no. 1 Mei. 2018.

Wina, Levia dkk. Hubungan Pola Asuh Orang Tua Dengan Perkembangan Sosial Anak Usia Prasekolah (4-6 Tahun) Di Tk Muslimat Ar-Rohmah Gading Kembar Kecamatan Jabung Kabupaten Malang, Universitas Tribhuwana Tunggadewi Malang, jurnal diakses pada tanggal 27 Mei 2021.

Suranto, AW. Komunikasi Sosial Budaya. Yogyakarta: Graha Ilmu. 2010.

Rakhmat, J. Psikologi Komunikasi. Bandung: Remaja Rosdakarya. 2004.

Surbakti, E. B. Sudah Siapkah Menikah?. Jakarta: Media Komputindo. 2008.

Ch, Mufidah. Psikologi Keluarga Islam Berwawasan Gender. Malang: UIN Maliki Press. 2013.

Citra, Sherly. Pola Komunikasi Orangtua dengan Anak Perokok Aktif di Surabaya. Surabaya: UPN Veteran. 2010. 